\title{
Divergent requirement for Gas and cAMP in the differentiation and inflammatory profile of distinct mouse Th subsets
}

\author{
Xiangli Li, ${ }^{1}$ Fiona Murray, ${ }^{1,2}$ Naoki Koide, ${ }^{1}$ Jonathan Goldstone,, ${ }^{1}$ Sara M. Dann,,1,3 \\ Jianzhong Chen, ${ }^{1}$ Samuel Bertin, ${ }^{1}$ Guo Fu, ${ }^{4}$ Lee S. Weinstein, ${ }^{5}$ Min Chen, ${ }^{5}$ \\ Maripat Corr, ${ }^{1}$ Lars Eckmann,, ${ }^{1}$ Paul A. Insel, ${ }^{1,2}$ and Eyal Raz ${ }^{1}$
}

\begin{abstract}
'Department of Medicine and 2Department of Pharmacology, UCSD, La Jolla, California, USA. ${ }^{3}$ Department of Internal Medicine, Department of Microbiology, University of Texas Medical Branch, Galveston, Texas, USA. ${ }^{2}$ Department of Immunology and Microbial Science, The Scripps Research Institute, La Jolla, California, USA. ${ }^{5}$ Metabolic Diseases Branch, National Institute of Diabetes and Digestive and Kidney Diseases, NIH, Bethesda, Maryland, USA.
\end{abstract}

\begin{abstract}
cAMP, the intracellular signaling molecule produced in response to GPCR signaling, has long been recognized as an immunosuppressive agent that inhibits $T$ cell receptor activation and $T$ cell function. However, recent studies show that cAMP also promotes $\mathrm{T}$ cell-mediated immunity. Central to cAMP production downstream of GPCR activation is the trimeric G protein Gs. In order to reconcile the reports of divergent effects of cAMP in $T$ cells and to define the direct effect of cAMP in $T$ cells, we engineered mice in which the stimulatory $G \alpha$ subunit of Gs (Gos) could be deleted in $\mathrm{T}$ cells using $\mathrm{CD} 4-\mathrm{Cre}\left(\mathrm{Gnas}^{\Delta C D 4}\right)$. Gnas ${ }^{\Delta C D 4} \mathrm{CD}^{+} \mathrm{T}$ cells had reduced cAMP accumulation and $\mathrm{Ca}^{2+}$ influx. In vitro and in vivo, $\mathrm{Gnas}^{\triangle \mathrm{CCD} 4} \mathrm{CD}^{+} \mathrm{T}$ cells displayed impaired differentiation to specific Th subsets: Th17 and Th1 cells were reduced or absent, but Th2 and regulatory $T$ cells were unaffected. Furthermore, $\mathrm{Gnas}^{\Delta C D 4} \mathrm{CD}^{+} \mathrm{T}$ cells failed to provoke colitis in an adoptive transfer model, indicating reduced inflammatory function. Restoration of cAMP levels rescued the impaired phenotype of Gnas ${ }^{\triangle C D 4}$ $\mathrm{CD}^{+} \mathrm{T}$ cells, reinstated the PKA-dependent influx of $\mathrm{Ca}^{2+}$, and enhanced the ability of these cells to induce colitis. Our findings thus define an important role for cAMP in the differentiation of Th subsets and their subsequent inflammatory responses, and provide evidence that altering cAMP levels in $\mathrm{CD} 4^{+} \mathrm{T}$ cells could provide an immunomodulatory approach targeting specific Th subsets.
\end{abstract}

\section{Introduction}

The stimulatory $G \alpha$ subunit (Gas) of the trimeric $G$ protein $G$ s plays a central role in GPCR-mediated signal transduction by coupling the receptors to the activation of adenylyl cyclase (AC) and increased synthesis of cAMP (1). Increases in cAMP can inhibit T cell function, e.g., blunting $\mathrm{CD}^{+} \mathrm{T}$ cell activation, proliferation, and production of certain cytokines, such as IFN- $\gamma$ and TNF- $\alpha$ $(2,3)$. In contrast to these data, cAMP has also been shown to stimulate inflammation by promoting Th17 cell expansion (4-6). For example, the mucosal adjuvant cholera toxin (CT), via a cAMP-dependent mechanism, provokes Th17 immune response at mucosal sites (7).

To help resolve such discrepant findings regarding the role of cAMP in $\mathrm{CD}^{+}{ }^{+}$Th cell differentiation and function, we generated conditional knockout mice whose $\mathrm{CD}^{+} \mathrm{T}$ cells lack the gene for Gas (Gnas ${ }^{\triangle C D 4}$ mice) and thus have decreased production of cAMP. We found that $\mathrm{CD}^{+} \mathrm{T}$ cells isolated from $\mathrm{Gnas}^{\Delta C D 4}$ mice had reduced cAMP levels, decreased $\mathrm{Ca}^{2+}$ influx, and weak Th17 and Th1 responses but normal Th2 and Treg responses both in vitro and in vivo. Our data thus suggest that cAMP in $\mathrm{CD}^{+} \mathrm{T}$ cells is proinflammatory by altering the differentiation and activation of Th subsets.

\section{Results}

$\mathrm{Gnas}^{\Delta C D 4} \mathrm{CD4^{+ }}$ T cell mice have reduced IL-17 and IFN- $\gamma$ production. GPCR-mediated increase in intracellular cAMP requires the activation of AC by Gas (3). We used the Cre-loxP system to generate

Conflict of interest: The authors have declared that no conflict of interest exists. Citation for this article: J Clin Invest. 2012;122(3):963-973. doi:10.1172/JCI59097. mice with a deletion of Gnas (the gene that encodes Gas) targeted to T cells (8). The targeted genetic deletion of Gas with CD4-Cre occurs at the $\mathrm{CD} 4^{+} \mathrm{CD} 8^{+}$stage. Consequently, we found that both peripheral $\mathrm{CD}^{+}$and $\mathrm{CD}^{+} \mathrm{T}$ cells from Gnas ${ }^{\Delta C D 4}$ mice lacked Gas expression (Figure 1A). Gnas ${ }^{\triangle C D 4}$ and WT mice had similar numbers of $\mathrm{CD}^{+}$and $\mathrm{CD}^{+} \mathrm{T}$ cells and a similar percentage of effector memory $\left(\mathrm{CD} 44^{\mathrm{hi}} \mathrm{CD} 62 \mathrm{~L}^{\mathrm{lo}}\right)$ and naive $\left(\mathrm{CD} 44^{\mathrm{lo}} \mathrm{CD} 62 \mathrm{~L}^{\mathrm{hi}}\right) \mathrm{CD} 4^{+}$and $\mathrm{CD} 8^{+}$ T cells (Supplemental Figure 1, A-E; supplemental material available online with this article; doi:10.1172/JCI59097DS1), indicating that the loss of Gas did not affect T cell development overall.

Figure $1 \mathrm{~B}$ shows that compared with WT CD4 $4^{+}$cells, $\mathrm{CD}^{+} \mathrm{T}$ cells from $\mathrm{Gnas}^{\triangle C D 4}$ mice, have blunted cAMP accumulation in response to the AC activator forskolin and the agonists of Gas-coupled GPCRs $\mathrm{PGE}_{2}$ and isoproterenol in the presence of the phosphodiesterase 4 (PDE4) inhibitor rolipram. Rolipram was used based on the high expression of PDE4B and the greater ability of PDE4 inhibitors to increase cAMP compared with other family-specific PDE inhibitors in $\mathrm{CD}^{+} \mathrm{T}$ cells (Supplemental Figure 2). Reduced cAMP accumulation in $\mathrm{Gnas}^{\Delta C D 4} \mathrm{CD} 4^{+} \mathrm{T}$ cells in response to AC activation by forskolin is consistent with the observation that Gas is necessary for maximal forskolin-stimulated AC activation (9). GPCR-stimulated cAMP levels were similar in CD11 $\mathrm{c}^{+}$bone marrow-derived dendritic cells (BMDCs) from Gnas ${ }^{\triangle C D 4}$ and WT mice (Figure 1C), consistent with a $\mathrm{T}$ cell-specific deletion of Gas (Figure 1A).

Assessment of the cytokine profile of $\mathrm{CD}^{+} \mathrm{T}$ cells isolated from the $\mathrm{Gnas}^{\triangle C D 4}$ mice revealed lower levels of IL-17A, IL-22, and IFN- $\gamma$ production upon stimulation with anti-CD3/CD28 Abs compared with the responses of WT CD4 ${ }^{+} \mathrm{T}$ cells (Figure 1D). Despite the change in the cytokine profile, we observed no significant differ- 


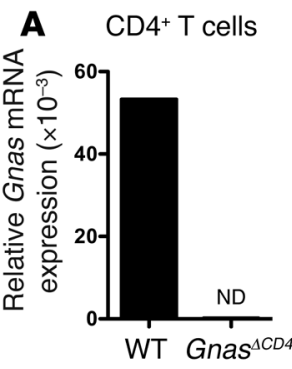

$\mathrm{CD}^{+} \mathrm{T}$ cells

$B$ cells

CD11c $\mathrm{c}^{+} \mathrm{DCs}$
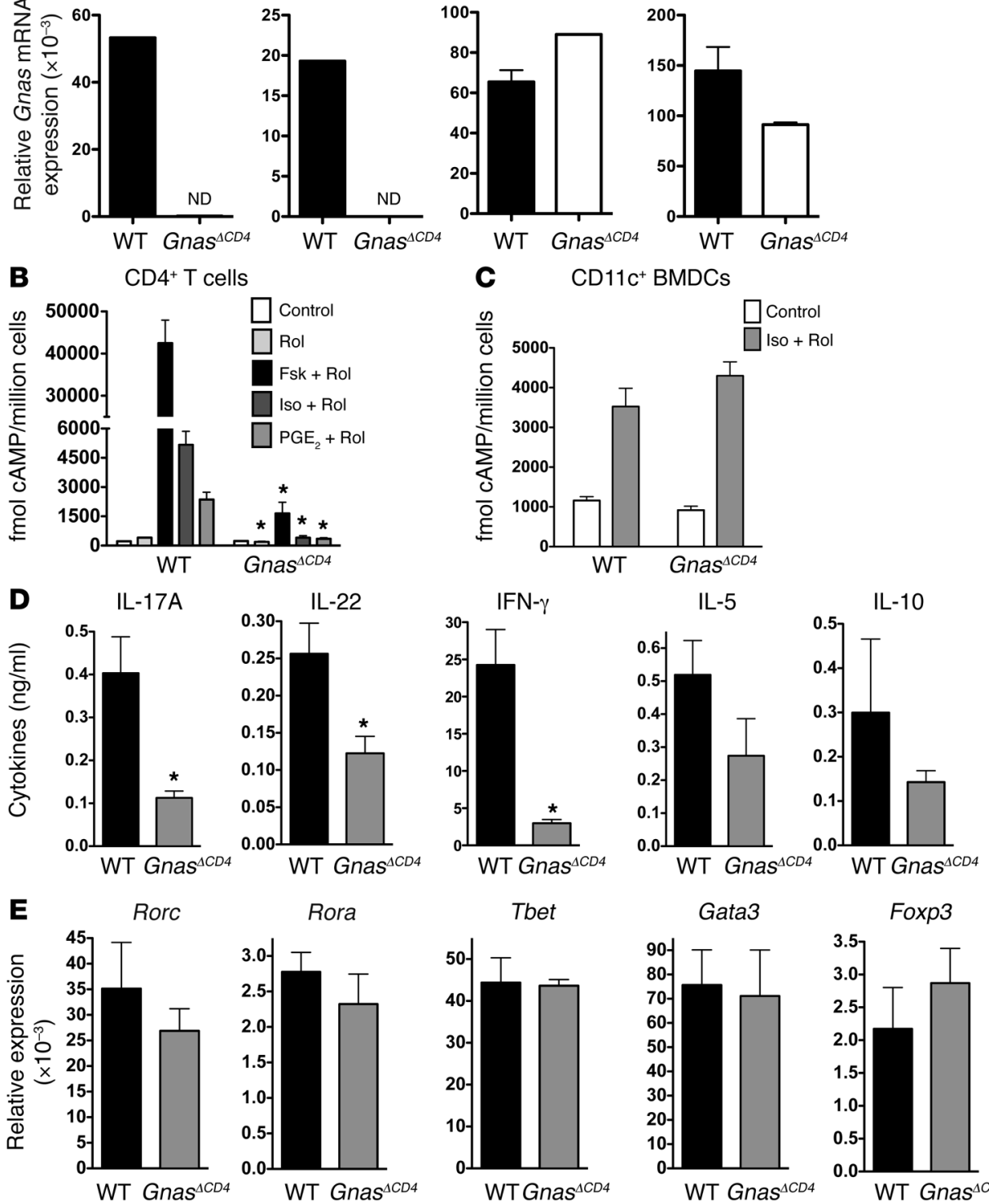
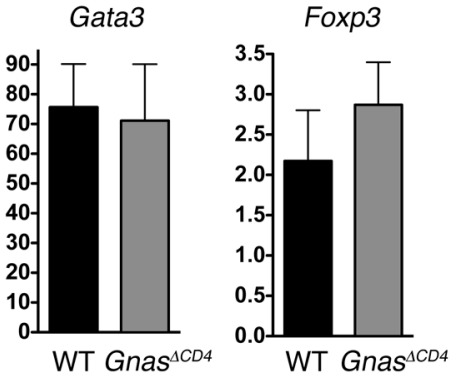

Figure 1

Reduced CAMP, IL-17, and IFN- $\gamma$ production in $\mathrm{Gnas}^{\triangle C D 4} \mathrm{CD} 4^{+} \mathrm{T}$ cells. (A) Deficient expression of Gnas mRNA in $\mathrm{Gnas}^{\triangle C D 4} \mathrm{CD}^{+}$and CD8 ${ }^{+}$ $T$ cells. Messenger RNA was prepared from sorted splenic CD4 T cells $\left(\mathrm{TCR} \beta^{+} \mathrm{CD} 4^{+}\right), \mathrm{CD}^{+} \mathrm{T}$ cells $\left(\mathrm{TCR} \beta^{+} \mathrm{CD} 8^{+}\right)$, B cells (TCR $\left.\beta^{-} \mathrm{CD} 19^{+}\right)$, and DCs (CD11 ${ }^{+}$TCR $\beta^{-}$CD19-). ND, not detected. (B) Reduced cAMP accumulation in $\mathrm{CD}^{+} \mathrm{T}$ cells of Gnas $^{\triangle C D 4}$ mice. cAMP accumulation was assessed in $C D 4^{+} T$ cells from WT and Gnas $^{\triangle C D 4}$ mice treated with vehicle, forskolin (Fsk), isoproterenol (Iso), or $\mathrm{PGE}_{2}$ in the presence of the PDE4 inhibitor rolipram (Rol). Data are mean \pm SEM, $n=3$, from a representative experiment of 3 with similar results; ${ }^{*} P<0.05$, Gnas ${ }^{\Delta C D 4}$ compared with WT cells under the same conditions. (C) cAMP accumulation in $\mathrm{CD} 11 \mathrm{c}^{+}$BMDCs from WT and Gnas ${ }^{\triangle C D 4}$ mice treated with vehicle or isoproterenol in the presence of rolipram. (D) Reduced Th17 and Th1 cytokine in Gnas ${ }^{\triangle C D 4}$ CD4+ T cells. Splenic CD4+ $T$ cells from WT or Gnas ${ }^{\triangle C D 4}$ mice were stimulated by anti-CD3/CD28 Abs for 72 hours, and the levels of cytokines were determined (ELISA). $n=7-8$ for each group from 2 experiments with similar results; ${ }^{*} P<0.05$. (E) mRNA levels of transcription factors in Gnas ${ }^{\triangle C D 4} \mathrm{CD} 4^{+}$ $T$ cells. Messenger RNA was prepared from cells used in $\mathbf{D}$ to assess transcription factors by quantitative PCR. The expression levels (A and E) were normalized to the expression of the Rplpo housekeeping gene. ences in the mRNA levels of the Th17- and Th1-lineage commitment transcription factors Rorc and Tbet (Figure 1E), suggesting that lineage commitment is not altered in Gnas ${ }^{\triangle C D 4}$ mice. Functionally Gnas ${ }^{\triangle C D 4}$ mice also had reduced ability to clear Citrobacter rodentium compared with WT mice despite similar bacterial loads at 1 week after infection (Supplemental Figure $1 \mathrm{~F}$ ). Also, the CD4 ${ }^{+}$ $\mathrm{T}$ lymphocytes from the colon lamina propria (LPLs) of Gnas ${ }^{\triangle C D 4}$ infected mice had a lower expression of IL-17A ${ }^{+}$cells and IFN- $\gamma^{+}$ cells (Supplemental Figure 1G).

We also evaluated the possible contribution of $\mathrm{CD}^{+} \mathrm{T}$ cells and BMDCs from Gnas ${ }^{\triangle C D 4}$ mice to $\mathrm{CD} 4^{+} \mathrm{T}$ cell function. As shown in Supplemental Figure 3, deletion of Gas in these cells did not affect OVA-specific $\mathrm{CD}^{+} \mathrm{T}$ cells responses.

Gnas ${ }^{\Delta C D 4}$ mice do not mount an antigen-specific Th17 response. The data generated with anti-CD3/CD28 Ab stimulation (Figure 1D) suggest a defect in Th17 cytokine production by nnas $^{\Delta C D 4} \mathrm{CD}^{+}$ $\mathrm{T}$ cells. To determine antigen-specific Th17 immune responses in Gnas ${ }^{\triangle C D 4} \mathrm{CD}^{+} \mathrm{T}$ cells, we used in vitro and in vivo immunization protocols with OVA and CT (7). Figure 2A shows that compared with control OT-2 cells, OT-2/Gnas ${ }^{\Delta C D 4} \mathrm{CD}^{+} \mathrm{T}$ cells differentiated in vitro had reduced production of Th17 cytokines (IL-17A and IL-22). Furthermore, $\mathrm{CD}^{+} \mathrm{T}$ cells isolated from the spleens of in vivo OVA/CT-immunized WT mice, but not Gnas ${ }^{\Delta C D 4}$ mice, mounted OVA-specific IL-17A and IL-22 responses (Figure 2B). Consistent with previous data (7), we did not detect OVA-specific IL-17F and IL-21 production in OVA-stimulated CD4 ${ }^{+} \mathrm{T}$ cell cultures (Figure 2, A and B). Collectively, the data in Figures 1 and 2 provide evidence that Gas-mediated signaling in $\mathrm{CD}^{+} \mathrm{T}$ cells is necessary for Th17 response.

Gnas ${ }^{\triangle C D 4} \mathrm{CD}^{+} \mathrm{T}$ cells fail to induce colitis. Adoptive transfer of naive WT CD4 $4^{+} \mathrm{T}$ cells into Rag $1^{-/-}$recipients provokes colitis, because $\mathrm{CD} 4^{+} \mathrm{T}$ cells acquire a colitogenic Th 1 and/or a Th17 phenotype $(10,11)$. We investigated whether $\mathrm{Gnas}^{\Delta C D 4} \mathrm{CD}^{+} \mathrm{T}$ cells develop this colitogenic phenotype in the adoptive transfer model. The transfer of WT CD4 $4^{+} \mathrm{T}$ cells into Rag1-/- mice produced greater loss in body weight (Figure 3A), higher disease activity index 


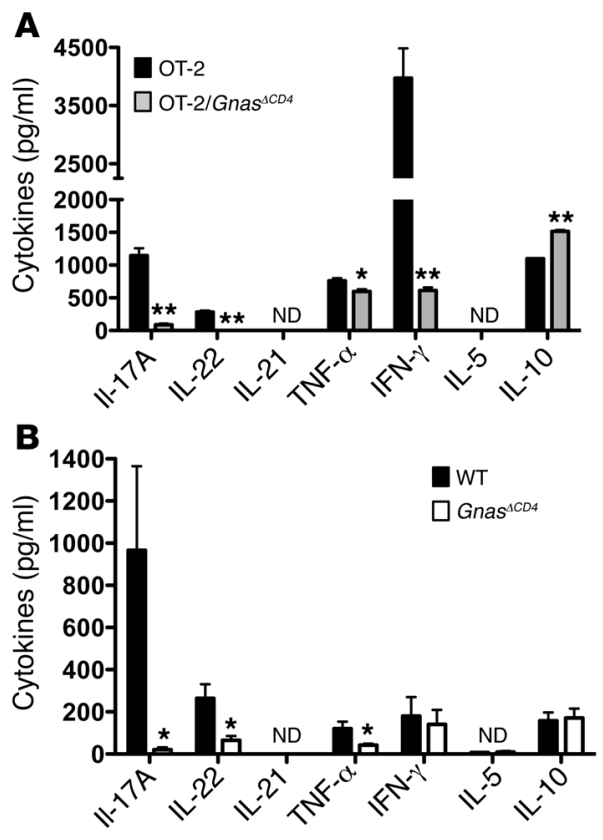

(Figure 3B), and more severe colonic inflammation than the transfer of Gnas ${ }^{\Delta C D 4} \mathrm{CD} 4^{+} \mathrm{T}$ cells (Figure $3 \mathrm{C}$ ). Consistent with these findings, we found lower levels of IL-17A, IL-22, and IFN- $\gamma$ in the colonic explants of recipients transferred with $\mathrm{Gnas}^{\Delta C D 4} \mathrm{CD} 4^{+} \mathrm{T}$ cells (Figure 3D). However, we were unable to recover sufficient Gnas $^{\Delta C D 4} \mathrm{CD}^{+} \mathrm{T}$ cells from LPLs as compared with WT mice for detailed studies. Gnas ${ }^{\Delta C D 4} \mathrm{CD}^{+} \mathrm{T}$ cells isolated from recipients' spleens 4 weeks after transfer displayed fewer IFN- $\gamma^{+}$, IFN- $\gamma^{+}$IL-17A ${ }^{+}$, and TNF- $\alpha^{+} \mathrm{CD}^{+} \mathrm{T}$ cells than did cells isolated from the spleen of Rag1 1/- mice that received WT CD4 ${ }^{+} \mathrm{T}$ cells (Figure $3 \mathrm{E}$ ). These results provide further evidence for the contribution of Gas to Th1 and Th17 differentiation but do not exclude a defect in the cells' ability to migrate to the colon.

$\mathrm{Gnas}^{\Delta \mathrm{CD} 4} \mathrm{CD}^{+} \mathrm{T}$ cells display reduced $\mathrm{Th} 17$ and Th1 cell differentiation in vitro. Figures 1-3 indicate a role for Gas in the acquisition of Th17 and Th1 effector functions. To further elucidate the role of Gas in Th subset differentiation of $\mathrm{CD}^{+} \mathrm{T}$ cells, we used an in vitro differentiation system for each Th subset: after FACS sorting of naive $\mathrm{CD}^{+} \mathrm{T}$ cells from the spleens of WT and Gnas ${ }^{\Delta C D 4}$ mice, we cultured the cells for 4 days under Th17, Th1, Th2, and Treg polarization conditions; stimulated the cells with PMA/ionomycin; and assessed (by flow cytometry) the intracellular levels of IL-17, IFN- $\gamma$, IL-4, and Foxp3 (Figure 4). WT CD4 $4^{+} \mathrm{T}$ cells had a 2.8-fold greater increase (i.e., $41.6 \%$ vs. $14.9 \%$ ) in IL-17-producing cells (Th17) in response to an IL-6/TGF- $\beta$ differentiation protocol (12) and a 22-fold increase in IL-17-producing cells (Th17) in response to an IL-6/IL-23/IL-1 differentiation protocol (13) compared with Gnas ${ }^{\triangle C D 4}$ mice (Figure 4A), thus demonstrating a role for Gas in Th17 differentiation. Furthermore, WT CD4+ $4^{+}$cells had an 81fold increase in IFN- $\gamma$-producing cells (Th1, Figure 4B) but a similar number of IL-4-producing cells (Th2, Figure 4C) compared with Gnas $^{\Delta C D 4} \mathrm{CD}^{+} \mathrm{T}$ cells. We also observed no significant differences in Tregs between WT and Gnas ${ }^{\triangle C D 4}$ mice: Foxp $3^{+}$expression (Figure 4D) and stability (Supplement Figure 4A), IL-10 production (Supplemental Figure 4B), and the suppressive effect on WT $\mathrm{CD}^{+} \mathrm{T}$ cell proliferation (Supplemental Figure 4C) were similar

\section{Figure 2}

Gas-mediated signaling in CD4+ T cells promotes antigen-specific Th17 cell response. (A) Decreased IL-17A and IL-22 in Gnas ${ }^{\triangle C D 4}$ CD4 + OT-2 cells. Enriched splenic CD4+ T cells from OT-2 or OT-2/Gnas ${ }^{\triangle C D} 4$ mice were cocultured with WT CD11 $\mathrm{c}^{+}$splenic DCs at a 2:1 ratio for 5 days in the presence of class II OVA-derived peptide. The OT-2 cells were restimulated by plate-bound anti-CD3/28 Abs for 24 hours, and the cytokine levels were determined (ELISA). Data are mean \pm SEM; $n=3$; ${ }^{\star} P<0.05,{ }^{* *} P<0.01$. (B) Gas-mediated signaling in $\mathrm{CD} 4+\mathrm{T}$ cells promotes OVA-specific Th17 cell response in vivo. WT or Gnas ${ }^{\triangle C D 4}$ mice immunized orally with CT and OVA. After 42 days, the splenocytes were collected and restimulated with OVA for 3 days in vitro, and the levels of cytokines were determined in the supernatants (ELISA). Data are mean \pm SEM; $n=6$, from 2 experiments; ${ }^{*} P<0.05$ by MannWhitney $U$ test.

in Tregs from WT and Gnas ${ }^{\Delta C D 4}$ mice. Taken together, these data suggest that Gas in $\mathrm{CD}^{+} \mathrm{T}$ cells regulates Th17 and Th1, but not Th2 or Treg, cell differentiation.

cAMP restores the ability of $\mathrm{Gnas}{ }^{\triangle C D}{ }^{\mathrm{C}} \mathrm{CD} 4^{+} \mathrm{T}$ cells to promote $\mathrm{Th} 17$ and Th1 differentiation. Since Gnas ${ }^{\triangle C D 4} \mathrm{CD}^{+} \mathrm{T}$ cells have blunted cAMP accumulation, we hypothesized that addition of exogenous cAMP would reverse the effects of the genetic deletion. We thus treated Gnas $^{\Delta C D 4}$ FACS-sorted naive CD4 ${ }^{+}$T cells cultured under Th 17 and Th1 polarization conditions with 8 bromo-cAMP (8Br-cAMP), a cell-permeable cAMP analog, and found (Figure 5A) a 2.1-fold increase in IL- $17^{+}$cells in response to the IL-6/TGF- $\beta$ differentiation and a 3.3-fold increase in response to the IL-6/IL-23/IL-1 $\beta$ differentiation protocol. The increase in $\mathrm{IL}-17^{+}$cells by $8 \mathrm{Br}-\mathrm{cAMP}$ was dose dependent (Supplemental Figure 5A). 8Br-cAMP treatment of WT CD $4^{+}$T cells increased Th 17 cells by $50 \%$ (Figure $5 \mathrm{~A}$ ) under both Th17 polarization conditions and increased IL-17 ${ }^{+}$TNF- $\alpha^{+}$cells by $50 \%-200 \%$ in both WT and Gnas ${ }^{\Delta C D 4} \mathrm{CD}^{+} \mathrm{T}$ cells (Figure $5 \mathrm{~B}$ ). 8Br-cAMP increased $\mathrm{Gnas}^{\triangle C D 4} \mathrm{CD} 4^{+} \mathrm{IFN}-\gamma^{+} \mathrm{T}$ cells by 5.8 -fold (Figure 5C) and of Gnas ${ }^{\triangle C D 4}$ IFN- $\gamma^{+}$TNF- $\alpha^{+}$cells by 5.2-fold (Figure $5 \mathrm{D})$ but did not alter either cell population in $\mathrm{WT} \mathrm{CD}^{+} \mathrm{T}$ cells. 8Br-cAMP did not increase IL- $4^{+}$cells (Th2) or Foxp $3^{+}$cells (Tregs) in either WT or Gnas ${ }^{\triangle C D 4} \mathrm{CD}^{+} \mathrm{T}$ cells, further implying that cAMP has divergent effects on Th subset differentiation (Supplemental Figure 5, B and C). Collectively, these data indicate that Gnas ${ }^{\triangle C D 4}$ $\mathrm{CD}^{+} \mathrm{T}$ cells lack normal Th17 and Th1 differentiation as a result of reduced cAMP accumulation.

Transcriptional regulation of Th17 differentiation in $\mathrm{Gnas}^{\triangle \mathrm{CD} 4} \mathrm{CD}^{+} \mathrm{Tcells}$. The reduced number of $\mathrm{IL}-17^{+}$cells from Gnas ${ }^{\Delta \mathrm{CD} 4} \mathrm{CD} 4^{+} \mathrm{T}$ cells (Figure 4) and the restoration of IL-17 production by $8 \mathrm{Br}$-cAMP (Figure 5) might imply that cAMP regulates the expression of transcription factors involved in Th17 differentiation (14). However, the presence of $8 \mathrm{Br}$-cAMP produced no significant changes in the mRNA levels of Rorc (15), Ror $\alpha$, or aryl-hydrocarbon receptor $(A h r)$ under either IL-6/TGF- $\beta$ or IL-6/IL-23/IL-1 $\beta$ polarization conditions (Supplemental Figure 6, A-C). The expression of Rorc mRNA in WT and Gnas ${ }^{\Delta C D 4} \mathrm{CD}^{+} \mathrm{T}$ cells was comparable during Th17 differentiation (Supplemental Figure $7 \mathrm{~A}$ ), even though the mRNA level of Il17a was reduced in Gnas ${ }^{\Delta C D 4}$ $\mathrm{CD}^{+} \mathrm{T}$ cells (Supplemental Figure 7B).

Since the phosphorylation of Stat 3 by IL- 6 or IL- 23 is mandatory for Th17 differentiation, we investigated its phosphorylation in WT and $\mathrm{Gnas}^{\triangle C D 4} \mathrm{CD} 4^{+} \mathrm{T}$ cells $(16,17)$. As shown in Supplemental Figure 8, we found elevated levels of Stat 3 phosphorylation in Gnas $^{\Delta C D 4} \mathrm{CD}^{+} \mathrm{T}$ cells under each Th17 differentiation condition. We conclude that the lower number of IL-17 ${ }^{+}$cells among Gnas ${ }^{\Delta C D 4}$ 


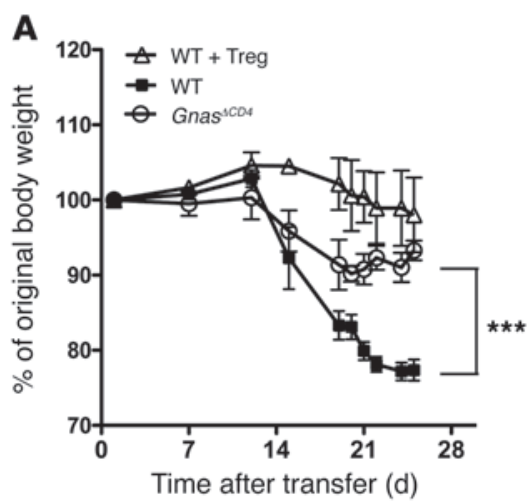

D
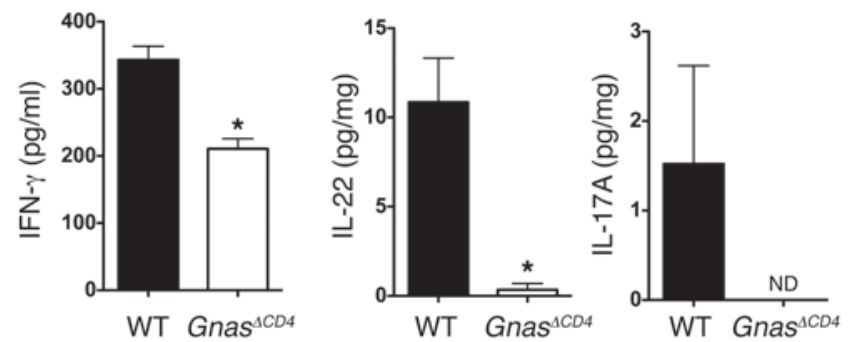

C
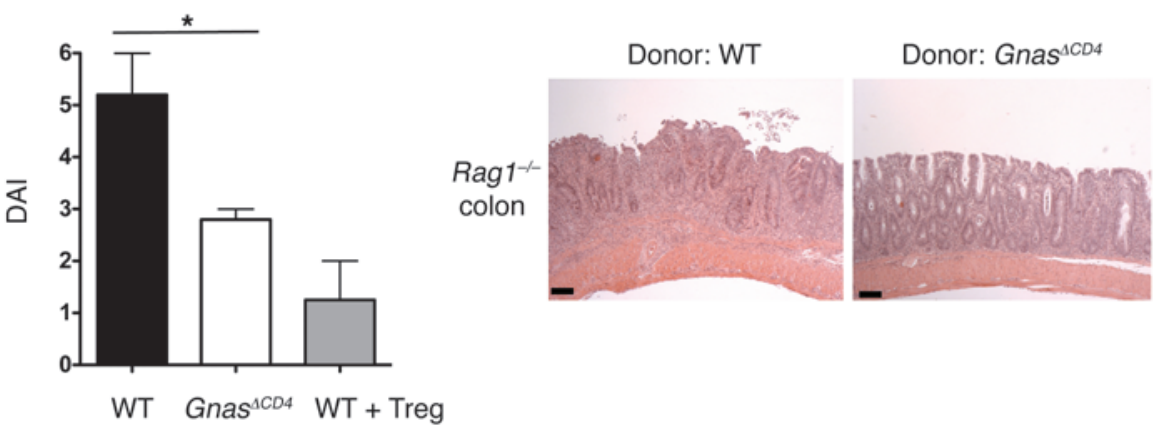

E

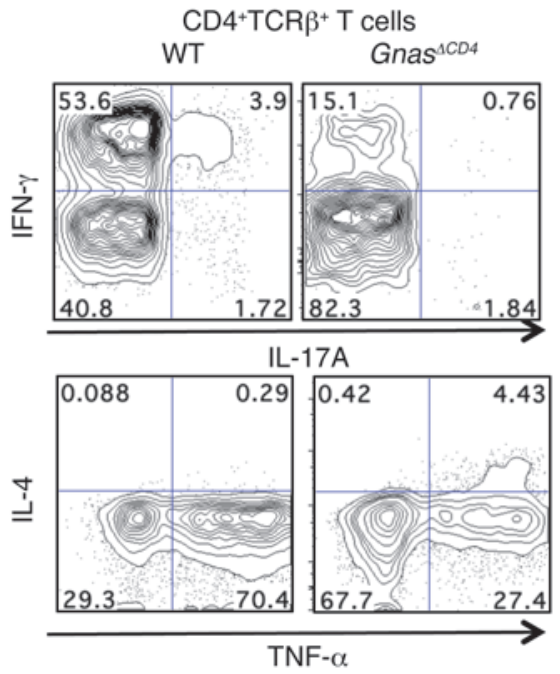

Figure 3

Gnas $^{\triangle C D 4}$ CD4 $4^{+}$T cells fail to induce colitis. (A) Percentage of initial body weight of Rag $1^{-1-}$ recipients transferred with WT or Gnas ${ }^{\triangle C D 4} \mathrm{FACS}$-sorted naive CD45RB hiCD25- CD4+ T cells with or without the cotransfer of CD4 ${ }^{+} \mathrm{CD} 45 \mathrm{RB}^{\mathrm{lo}} \mathrm{CD} 25^{+}$Tregs; ${ }^{* \star \star} P<0.001$, between recipients receiving WT and Gnas ${ }^{\triangle C D 4}$ naive CD4 ${ }^{+}$T cells, by 2-way ANOVA. (B) Disease activity index (DAI) in recipient mice. (C) Minimal histological inflammation in the colons of recipients of transferred naive Gnas ${ }^{\triangle C D 4} C D 4^{+} T$ cells compared with severe inflammation in the colons of recipients of transferred naive WT CD4+ T cells (original magnification, $\times 50$, scale bars: $100 \mu \mathrm{M}$ ). (D) Cytokine levels in colon explant supernatants after 24 hours of culture. (E) Reduced IFN- $\gamma^{+}$and IL-17A+ CD4+ T cells in Gnas ${ }^{\triangle C D 4}$ donor CD4+ T cells. Enriched CD4+ T cells from spleens of recipient mice at day 30 after transfer were stimulated with PMA/ionomycin for 4 hours. Intracellular cytokine levels were determined by flow cytometry. The number in each quadrant indicates the frequency of cells. Representative plots from 2 similar experiments are shown. Data in $\mathbf{A}$, B, and $\mathbf{D}$ represent mean \pm SEM from an experiment representative of 3 independent experiments with similar results. ${ }^{*} P<0.05$.

$\mathrm{CD}^{+} \mathrm{T}$ cells that was observed with Th17 polarization conditions was not due to an inhibition of ROR $\gamma t$ expression or Stat 3 activation during the Th17 differentiation program.

cAMP, via PKA, increases $\mathrm{Ca}^{2+}$ influx and promotes Th17 differentiation. Since $\mathrm{Ca}^{2+}$ influx is mandatory for TCR signaling and is regulated by cAMP in a number of cell types, we investigated whether $\mathrm{Ca}^{2+}$ had a role in the phenotype of Gnas ${ }^{\Delta C D 4} \mathrm{CD} 4^{+} \mathrm{T}$ cells (18). TCR stimulation increased cAMP levels in $\mathrm{CD}^{+} \mathrm{T}$ cells, implying a physiological role for cAMP in $\mathrm{T}$ cell activation (Supplemental Figure 9). $\mathrm{Ca}^{2+}$ influx was reduced in $\mathrm{Gnas}^{\Delta C D 4} \mathrm{CD}^{+} \mathrm{T}$ cells compared with WT CD4 ${ }^{+} \mathrm{T}$ cells (Figure $6 \mathrm{~A}$ ); this reduction could be reversed by addition of $8 \mathrm{Br}$-cAMP (Figure 6, B and C). The $\mathrm{Ca}^{2+}$ transport ATPase of intracellular store-operated $\mathrm{Ca}^{2+}$ channels (SERCA) is inhibited by thapsigargin (Tg) (12). Treatment with $\mathrm{Tg}$ did not alter intracellular $\mathrm{Ca}^{2+}$ levels in $\mathrm{CD}^{+} \mathrm{T}$ cells incubated in $\mathrm{Ca}^{2+}$-free medium (Figure 6D); however, upon $\mathrm{Ca}^{2+}$ addition, $\mathrm{Ca}^{2+}$ influx increased to a greater extent in WT CD4 ${ }^{+} \mathrm{T}$ cells than in Gnas $^{\triangle C D 4} \mathrm{CD}^{+} \mathrm{T}$ cells. These data imply that cAMP mediates
$\mathrm{Ca}^{2+}$ influx in $\mathrm{CD}^{+} \mathrm{T}$ cells, especially because we observed no differences in the mRNA expression of Orai13, Stim1 and Stim2, or L-type $\mathrm{Ca}^{2+}$ channels between WT and $\mathrm{Gnas}^{\Delta \mathrm{CD} 4} \mathrm{CD}^{+} \mathrm{T}$ cells (Supplemental Figure 10 and refs. 12, 19).

To determine whether the cAMP-mediated increase in $\mathrm{Ca}^{2+}$ influx is required for Th17 differentiation, we incubated FACS-sorted naive $\mathrm{CD}^{+} \mathrm{T}$ cells from WT and Gnas ${ }^{\triangle C D 4}$ mice under Th17 polarization conditions (IL-6/TGF- $\beta$ ) with $8 \mathrm{Br}$-cAMP in the presence or absence of the L-type $\mathrm{Ca}^{2+}$ channel blocker diltiazem (20). Diltiazem inhibited the increase in the number of Th $17^{+}$cells stimulated by $8 \mathrm{Br}$-cAMP in both WT and $\mathrm{Gnas}^{\triangle \mathrm{CD} 4} \mathrm{CD} 4^{+} \mathrm{T}$ cells (Figure $6 \mathrm{E}$ ). The increase in $\mathrm{Ca}^{2+}$ influx by cAMP is PKA dependent (21): Figure 7, $\mathrm{A}$ and $\mathrm{B}$, shows that the PKA inhibitor $\mathrm{H}-89$ reduced $\mathrm{Ca}^{2+}$ influx and the number of $\mathrm{IL}-17^{+}$cells induced by $8 \mathrm{Br}$ cAMP in $\mathrm{CD} 4^{+} \mathrm{T}$ cells under Th17 polarization conditions (IL-6/TGF- $\beta$ ). These data thus highlight a role for cAMP/PKA/Ca ${ }^{2+}$ in Th17 subset differentiation that is independent of lineage commitment factors, such as ROR $\gamma$ t. 
A

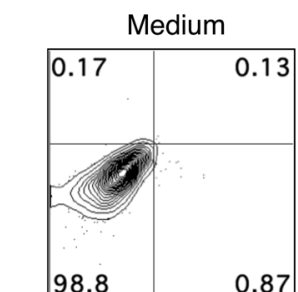

98.8

0.87

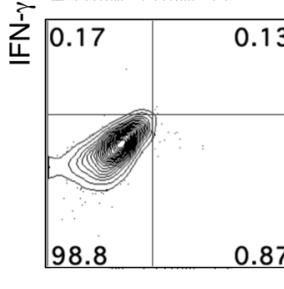

$0 . 8 7 \longdiv { 8 8 . 8 }$
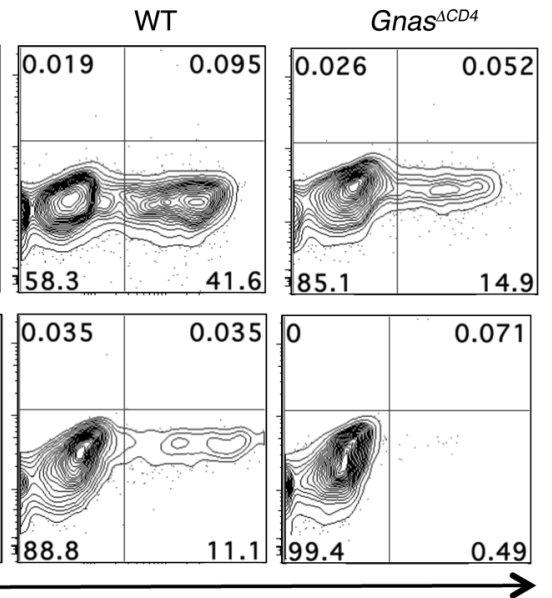

IL-17A

B

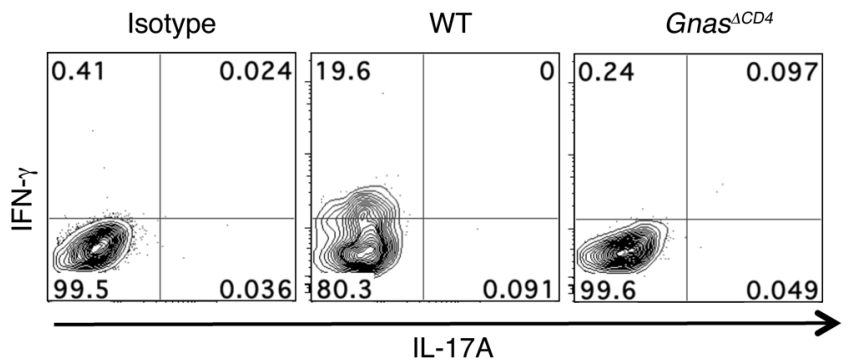

C
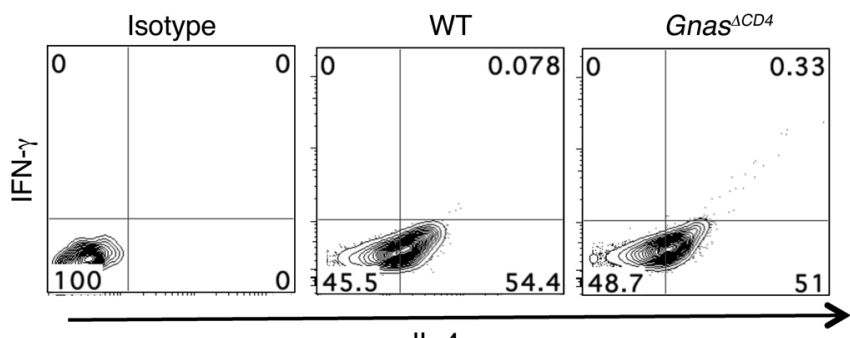

D

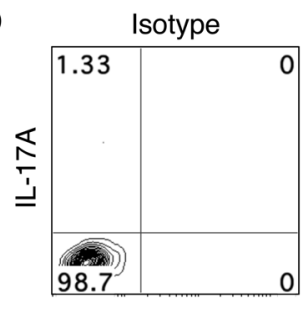

0 速 49

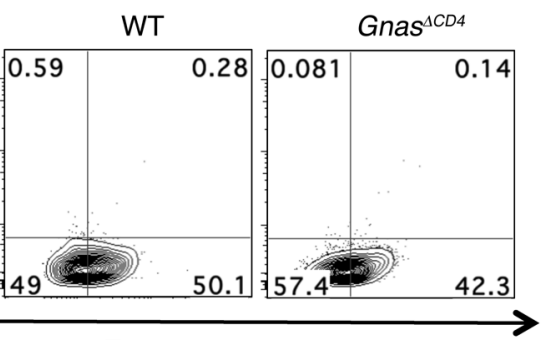

Foxp3

Figure 4

Reduced Th17 and Th1 cell differentiation of Gnas ${ }^{\triangle C D 4}$ naive CD4 ${ }^{+} \mathrm{T}$ cells in vitro. FACS-sorted naive $\mathrm{CD} 4^{+} \mathrm{T}$ cells from WT or Gnas ${ }^{\triangle C D 4}$ spleens were cultured for 4 days under Th polarization conditions for (A) Th17, (B) Th1, (C) Th2, and (D) Tregs as described in Methods. The CD4+ T cells were then stimulated with PMA/ionomycin for 4 hours. IL-17A, IFN- $\gamma$, IL-4, and Foxp3 levels were determined by flow cytometry. The number in each quadrant indicates the frequency of cells. Data are representative of 3 experiments with similar results.

cAMP enhances the colitogenicity of in vitro differentiated Th17 cells. To assess the in vivo effect of cAMP on Th17 cells, we transferred WT Th17 cells that were differentiated in vitro under IL-6/TGF- $\beta$ and IL-6/IL-23/IL-1 $\beta$ conditions in the absence or presence of $8 \mathrm{Br}$ cAMP into Rag1 $1^{-/-}$mice (Figure 8A and Supplemental Figure 11A).
Th17

$(\mathrm{IL}-6+\mathrm{TGF}-\beta)$

Th1

(IL-12)

Th2

(IL-4)

Treg

(TGF- $\beta+$ IL-2)

We then assessed the recipients over a 4-week period. Rag1 $1^{-/-}$mice that received Th17 cells that had been differentiated in the presence of $8 \mathrm{Br}$-cAMP developed more severe colitis compared with those that received Th17 cells differentiated without 8Br-cAMP (Figure 8, B and D, and Supplemental Figure 11, B and D). Consistent with previous reports of Th17 plasticity (22), $\mathrm{CD}^{+} \mathrm{T}$ cells isolated from the mesenteric lymph nodes and spleens of recipients displayed a phenotype different from that observed prior to their transfer. The in vitro differentiation of $\mathrm{CD} 4^{+} \mathrm{T}$ cells in the presence of $8 \mathrm{Br}$-cAMP resulted (after transfer) in a lower percentage of IL-17 ${ }^{+}$ cells, but a higher percentage of IFN- $\gamma^{+}$ cells and IL- $17^{+}$IFN- $\gamma^{+}$double-positive cells (Figure 8C and Supplemental Figure 11, A and C). These results highlight the proinflammatory role of cAMP in $\mathrm{CD}^{+}$ T cells and its ability to increase the colitogenic properties of Th17 cells.

\section{Discussion}

Gas mediates the activation of AC and generation of cAMP in response to GPCR agonists (1). Global Gas deficiency is embryonically lethal; therefore, we generated mice with a $T$ cell-selective deletion of Gas $(8,23,24)$. Gnas ${ }^{\triangle C D 4}$ CD4-Cre mice developed normally, but their $\mathrm{CD}^{+} \mathrm{T}$ cells did not accumulate cAMP; had reduced $\mathrm{Ca}^{2+}$ influx; secreted lower levels of IL-17, IL-22, and IFN- $\gamma$ (but normal IL-4) compared with WT CD4 ${ }^{+}$T cells; and did not mount an antigen-specific Th17 response upon CT/OVA immunization (Figure 2). The adoptive transfer of naive $G n a s^{\Delta C D 4} \mathrm{CD}^{+}$ $\mathrm{T}$ cells into $R a g 1^{-/-}$recipients provoked minimal colonic inflammation compared with that induced by the transfer of naive WT CD4 ${ }^{+} \mathrm{T}$ cells. Consistent with this phenotype, Gnas ${ }^{\Delta C D 4} \mathrm{CD} 4^{+} \mathrm{T}$ cells isolated from recipients' spleens displayed a lower frequency of IFN- $\gamma^{+}$, IFN- $\gamma^{+}$IL- $17^{+}$, and TNF- $\alpha^{+}$cells. To better elucidate the role of Gas in Th cell differentiation, we used an in vitro differentiation system. $\mathrm{CD}^{+} \mathrm{T}$ cells from Gnas ${ }^{\triangle C D 4}$ mice displayed fewer Th17 and Th 1 cells but comparable expression of Th 2 or Tregs relative to WT CD $4^{+} \mathrm{T}$ cells (Figure 4). Collectively, these in vitro and in vivo data indicate a divergent role for Gas in Th subset differentiation and function.

To determine whether the phenotype of $\mathrm{Gnas}^{\Delta C D 4} \mathrm{CD} 4^{+} \mathrm{T}$ cells was the result of reduced cAMP accumulation, we used 8Br-cAMP to restore cAMP levels and assessed in vitro Th differentiation. $8 \mathrm{Br}$ cAMP restored the expression of Gnas ${ }^{\Delta C D 4} \mathrm{IL}-17^{+}$and IFN- $\gamma^{+}$but did not alter IL-4 $4^{+}$or Foxp3 $3^{+} \mathrm{CD}^{+} \mathrm{T}$ cells, implying that reduced 
A

Medium

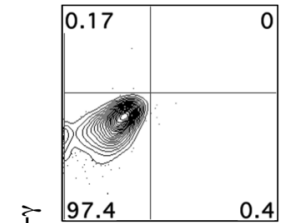

i

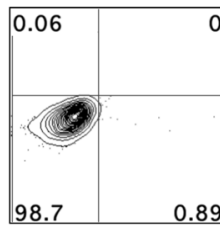

.4 $=53.3$

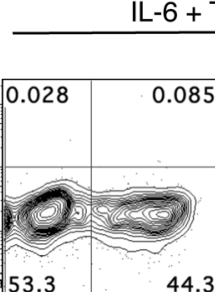

44.3

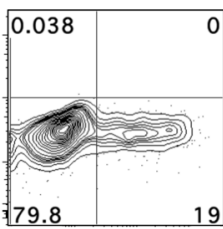

TGF- $\beta$
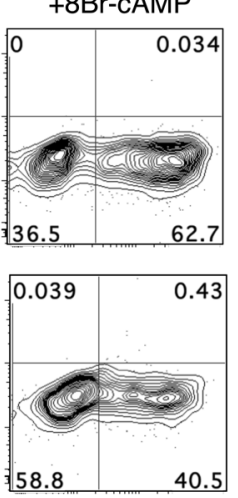

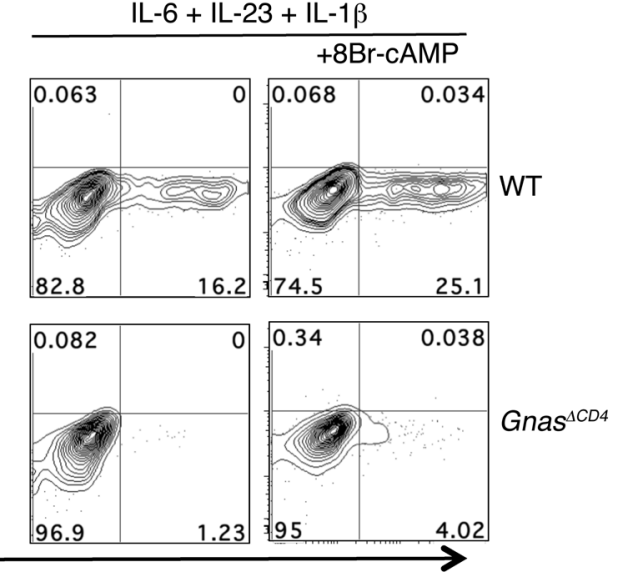

B Medium

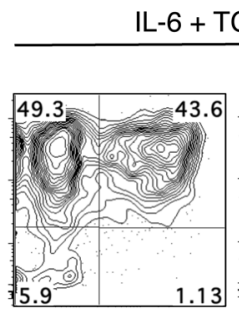

1.13
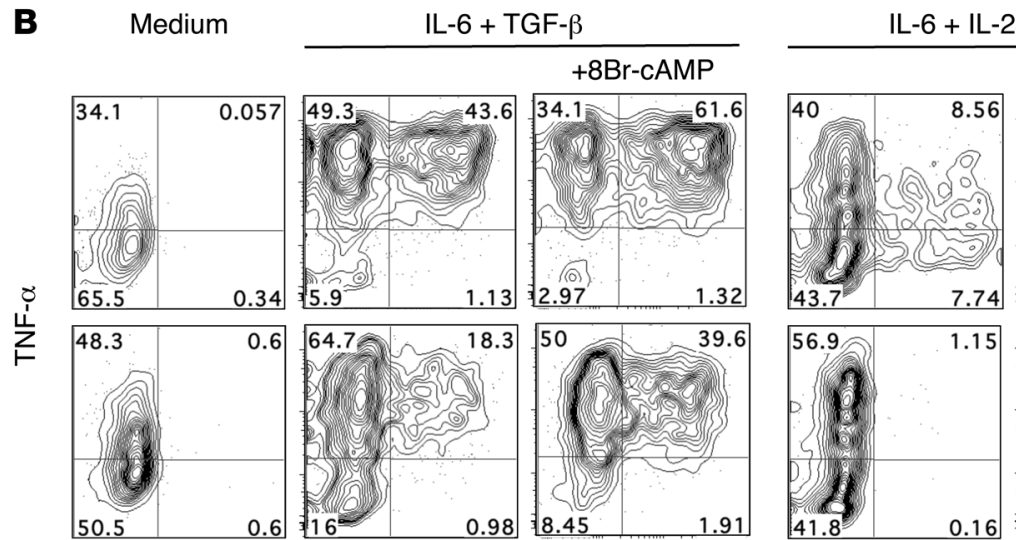

$23+I L-1 \beta$
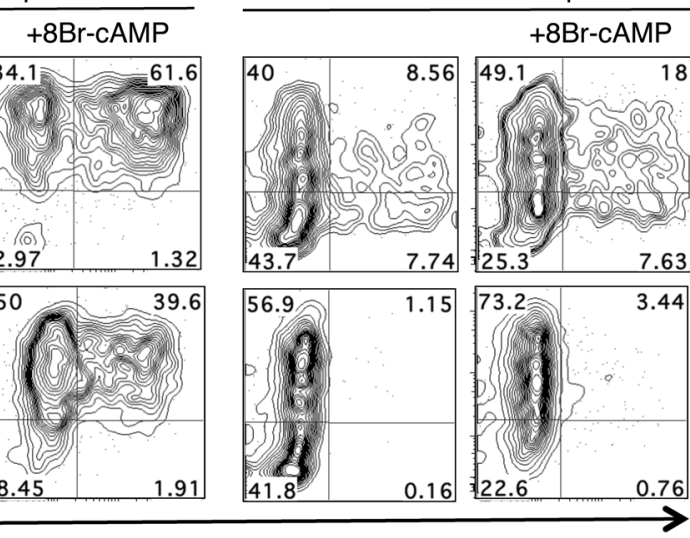

WT

$\operatorname{Gnas}^{\triangle C D 4}$

IL-17A

C

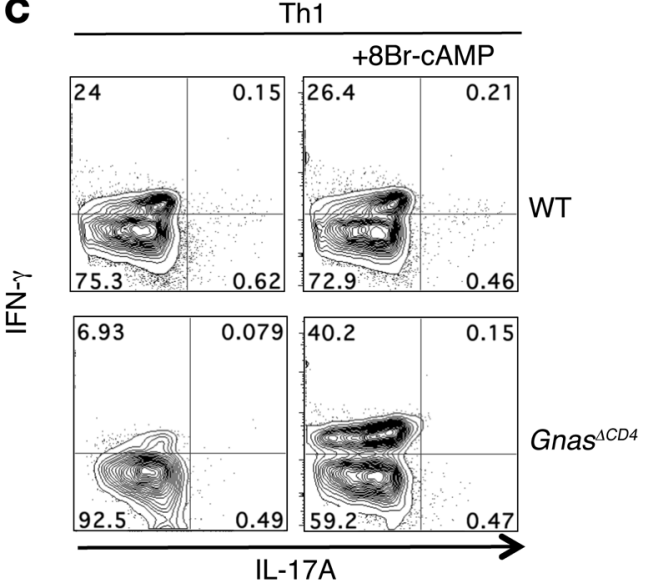

D

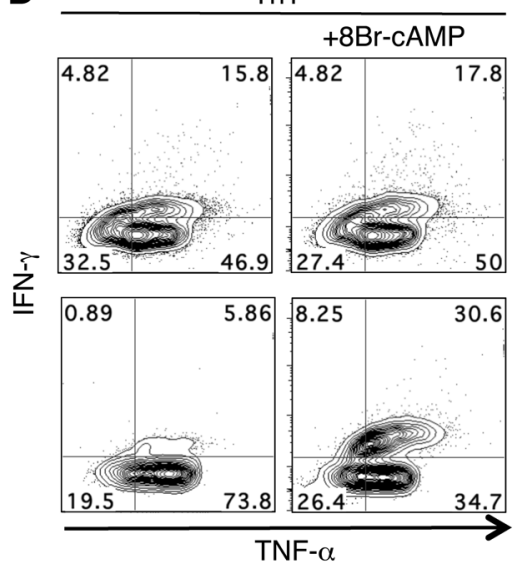

WT

Gnas $^{\triangle C D 4}$

\section{Figure 5}

cAMP restores Th17 and Th1 differentiation of Gnas ${ }^{\triangle C D 4}$ CD4 ${ }^{+}$T cells. (A and B) FACS-sorted naive CD4 ${ }^{+}$T cells from WT or Gnas ${ }^{\Delta C D 4}$ spleens were cultured for 4 days under two Th17 polarization conditions: IL-6/TGF- $\beta$ or IL-6/IL-23/IL-1 $\beta$ with or without $8 B r-c A M P(25 \mu M)$. (C and D) FACS-sorted naive CD4+ $T$ cells were cultured for 4 days under Th1 polarization conditions with or without $8 \mathrm{Br}-\mathrm{CAMP}(25 \mu \mathrm{M})$. The CD4+ $\mathrm{T}$ cells were stimulated with PMA/ionomycin for 4 hours, and the intracellular levels of IL-17A, IFN- $\gamma$, and TNF- $\alpha$ were determined by FACS analysis. The number in each quadrant indicates the frequency of cells. The data are representative of 3 independent experiments with similar results.

cAMP accumulation in Gnas ${ }^{\Delta C D 4} \mathrm{CD}^{+} \mathrm{T}$ cells selectively modulates Th17 and Th1 differentiation. Furthermore, restoring cAMP increased the expression of IL-17 $7^{+}$TNF- $\alpha^{+}$and IFN- $\gamma^{+}$TNF- $\alpha^{+}$cells, demonstrating that cAMP enhances the inflammatory phenotype of Th17 and Th1 subsets (Figure 5). The 8Br-cAMP-promoted
Th17 phenotype observed in $\mathrm{CD}^{+} \mathrm{T}$ cells from Gnas ${ }^{\Delta C D 4}$ mice was not associated with increased levels of Th17 lineage-specific transcription factors (Supplemental Figures 7 and 8), thus indicating that a transcriptional defect does not account for the impairment in Th17 differentiation. 
A

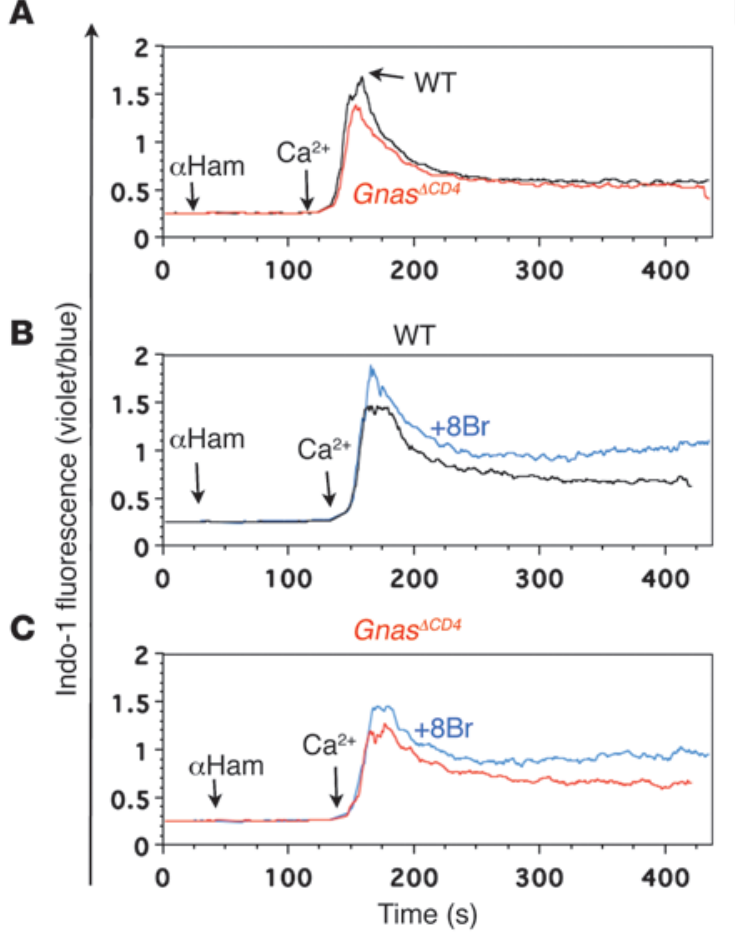

D

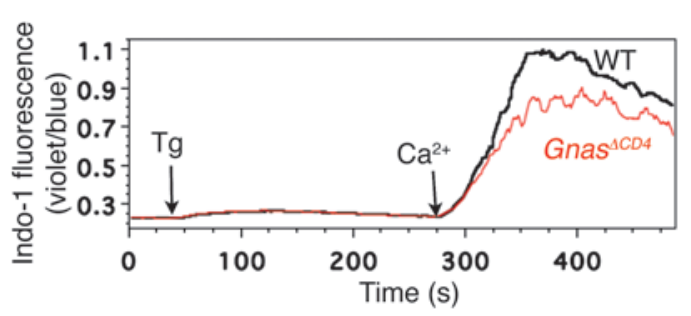

E

E Medium

IL-6 + TGF- $\beta$

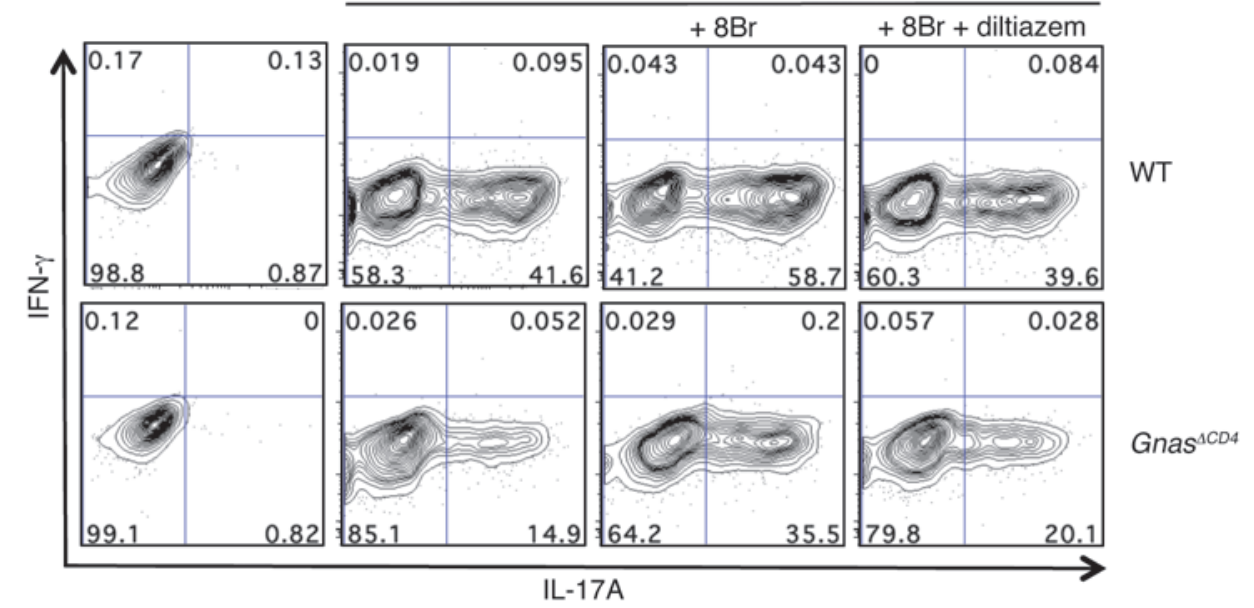

\section{Figure 6}

CAMP, via increasing $\mathrm{Ca}^{2+}$ influx, restores Th17 and Th1 differentiation of Gnas ${ }^{\triangle C D 4} \mathrm{CD} 4^{+} \mathrm{T}$ cells. (A-C) $\mathrm{Ca}^{2+}$ influx in enriched WT or Gnas $^{\triangle C D 4}$ splenic CD4+ $\mathrm{T}$ cells. CD4+ T cells stained with anti-CD3 Ab were cross-linked with goat anti-hamster Abs ( $\left.\alpha \mathrm{Ham}\right)$ in Ca ${ }^{2+-}$ free HBSS medium, followed by the addition of $\mathrm{CaCl}_{2}(2 \mathrm{mM})$; WT (CFSE-labeled) or Gnas ${ }^{\triangle C D 4} \mathrm{CD} 4+$ T cells (no label) were mixed, incubated with the calcium indicator Indo-1 AM, and assayed in one tube at the same time in the same environment. Ca ${ }^{2+}$ influx was measured by changes in the mean fluorescence ratio of Indo-1 AM at violet $(405 \mathrm{~nm})$ to blue laser $(510 \mathrm{~nm}) .8 \mathrm{Br}, 8 \mathrm{Br}-\mathrm{cAMP}, 25 \mu \mathrm{M}$. The data are representative of 1 of 3 independent experiments. (D) Reduced $\mathrm{Ca}^{2+}$ influx in Gnas ${ }^{\triangle C D 4}$ splenic CD4+ ${ }^{+}$cells stimulated by Tg. WT or Gnas ${ }^{\triangle C D 4}$ splenic CD4 ${ }^{+}$ T cells in $\mathrm{Ca}^{2+}$-free HBSS medium (EGTA, $0.5 \mathrm{mM}$ ) were stimulated by $\mathrm{Tg}(1 \mu \mathrm{M})$, followed by the addition of $\mathrm{CaCl}_{2}(2 \mathrm{mM})$. (E) Diltiazem inhibits the 8Br-cAMP increase in Th17 cells. FACS-sorted naive CD4+ $4^{+}$cells were cultured for 4 days under Th17 differentiation conditions (IL-6/TGF- $\beta$ ) as indicated. 8Br: $25 \mu \mathrm{M}$; diltiazem: $20 \mu \mathrm{M}$. The CD4+ T cells were stimulated with PMA/ionomycin for 4 hours. Intracellular cytokine levels were determined by flow cytometry. The number in each quadrant indicates the frequency of cells. Data are representative of 2 independent experiments with similar results.

In addition to the expression of lineage-specific transcription factors, differentiation of Th17 or Th1 cells is regulated by $\mathrm{Ca}^{2+}$ signaling, with $\mathrm{Ca}^{2+}$ influx primarily mediated by calcium releaseactivated channels (CRACs), inositol-1,4,5-trisphosphate receptors $\left(\mathrm{IP}_{3} \mathrm{Rs}\right)$, and L-type calcium channels $(25,26)$. Defective CRACs or
L-type calcium channels in $\mathrm{CD} 4^{+} \mathrm{T}$ cells can inhibit Th17 and Th1 cell differentiation without inhibiting the expression of ROR $\gamma t$ or T-bet (12). Since cAMP can activate L-type calcium channels (27), we postulated that $\mathrm{Gnas}^{\Delta C D 4} \mathrm{CD} 4^{+} \mathrm{T}$ cells have reduced $\mathrm{Ca}^{2+}$ influx that contributes to their Th phenotype. Indeed, we found that com- 
A

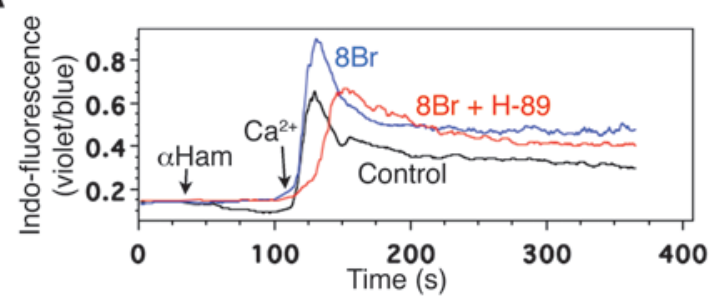

B

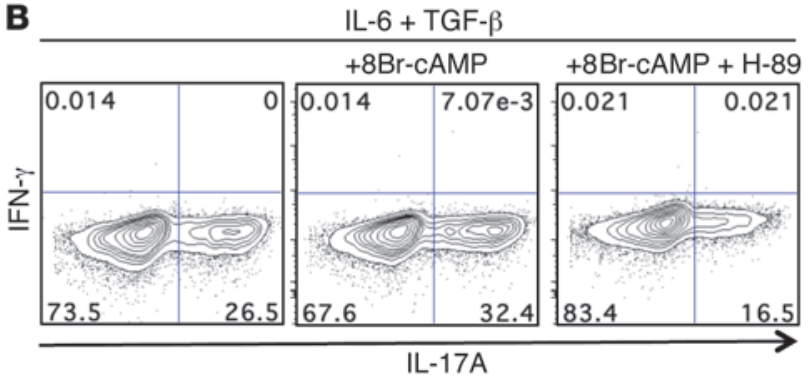

Figure 7

CAMP, via PKA, increases $\mathrm{Ca}^{2+}$ influx and promotes Th17 differentiation. (A) cAMP-mediated $\mathrm{Ca}^{2+}$ influx in WT $\mathrm{CD} 4^{+} \mathrm{T}$ cells is inhibited by PKA. CD4 ${ }^{+} \mathrm{T}$ cells stained with anti-CD3 Ab were crosslinked with goat anti-hamster Abs ( $\alpha \mathrm{Ham})$ in $\mathrm{Ca}^{2+}$-free HBSS medium, followed by the addition of $\mathrm{CaCl}_{2}(2 \mathrm{mM}) ; \mathrm{H}-89: 10 \mu \mathrm{M}, 15$ minutes preincubation; 8Br-cAMP, $25 \mu \mathrm{M}$. (B) cAMP promotes Th17 differentiation via PKA. FACS-sorted naive WT CD4+ $T$ cells were cultured for 4 days under Th17 differentiation conditions (IL-6/TGF- $\beta$ ) with the indicated reagents. $\mathrm{H}-89: 10 \mu \mathrm{M}, 30$ minutes preincubation. The number in each quadrant indicates the frequency of cells. Data are representative 3 independent experiments with similar results.

pared with WT CD4 $4^{+} \mathrm{T}$ cells, Gnas ${ }^{\triangle C D 4} \mathrm{CD}^{+} \mathrm{T}$ cells had reduced $\mathrm{Ca}^{2+}$ influx and a reduced Th17 polarization response and that this reduced response could be restored with $8 \mathrm{Br}$-cAMP; blocking $\mathrm{Ca}^{2+}$ channels inhibited the increase in Th17 cell number (Figure 6). Moreover, the cAMP-induced $\mathrm{Ca}^{2+}$ influx and subsequent Th17 differentiation were PKA dependent (Figure 7). Previous data have suggested that $\mathrm{Gas}$ can directly activate $\mathrm{Ca}^{2+}$ channels $(28,29)$ and non-receptor and receptor tyrosine kinases (30-32); however, our results indicating that addition of a cAMP analog could reverse the phenotype of the Gnas ${ }^{\triangle C D 4} \mathrm{CD} 4^{+} \mathrm{T}$ cells imply that the effects of Gas on Th subset differentiation is likely to be mediated, at least for the most part, by decreased cAMP accumulation in these cells.

Our in vitro data suggested that cAMP not only promotes Th17 and Th1 differentiation but also increases their inflammatory profile. To validate this finding in vivo, we transferred Th17 cells that were differentiated in vitro with or without $8 \mathrm{Br}$-cAMP into Rag $1^{-/-}$recipients and tested their ability to provoke colitis. Adding 8Br-cAMP increased the severity of colitis and the inflammatory profile of the $\mathrm{CD} 4^{+} \mathrm{T}$ cells 4 weeks after transfer (Figure 8 and Supplemental Figure 11). The adoptive transfer of $\mathrm{Gnas}^{\triangle C D 4}$ naive $\mathrm{CD} 4^{+}$ $\mathrm{T}$ cells into $\mathrm{Rag} 1^{-/-}$recipients resulted in a lower disease activity index and reduced destruction of the colonic mucosa compared with transfer of WT CD4 ${ }^{+} \mathrm{T}$ cells (Figure 3 ), further indicating a role for Gas-dependent cAMP production in the induction and/or maintenance of the inflammatory $\mathrm{CD} 4^{+} \mathrm{T}$ cell phenotype.

Taken together, our data show the importance of Gas and the synthesis and accumulation of cAMP and activation of PKA in the induction of Th17 and Th1 cell differentiation, as well as in the upregulation of their inflammatory responses. Importantly, these effects were not observed for Th2 cells, thus implying that their differentiation is independent of cAMP and cAMP/PKA-induced $\mathrm{Ca}^{2+}$ influx. This observation is consistent with evidence that the activation of Th1 and Th2 under the same conditions results in different patterns of $\mathrm{Ca}^{2+}$ signaling and cytokine production (33).

Our results thus indicate that cAMP has a proinflammatory and not, as previously proposed (3), an immunosuppressive effect, in terms of regulation of the function of Th cells. A possible explanation for differences in such results is that we assessed the role of cAMP during Th cell differentiation while others evaluated such a role after differentiation of Th cells. The Th-specific effects by cAMP suggest that it may be exploited for therapeutic immunomodulation. Such therapeutic effects might be achieved by targeting: (a) cAMP formation through the activation of Gas-coupled or inhibition of Gai-coupled GPCRs, (b) cAMP degradation by inhibiting PDE isoforms, or (c) L-type $\mathrm{Ca}^{2+}$ channels through their blockade in $\mathrm{CD}^{+} \mathrm{T}$ cells. It will be of interest to test such approaches in future studies.

\section{Methods}

Mice. C57BL/6 (B6) mice were purchased from Harlan, CD4-Cre transgenic mice from Taconic, and OT-2 (B6) mice expressing a transgenic TCR that recognize class II-derived OVA peptide and Rag1//- mice (B6) from The Jackson Laboratory. To generate Gas-deficient T cells, lox-flanked Gnas mice (8) were crossed to CD4-Cre mice. The T cells in the $\mathrm{Cre}^{+} \mathrm{Gnas}^{\triangle C D 4}$ mice were determined to be Gnas ${ }^{\triangle C D 4}$ and Gnas ${ }^{\triangle C D 8}$. The WT littermates (Cre ${ }^{-}$ $\left.G n a s^{f / f t}\right)$ or B6 mice were used as control (WT). To generate OVA-specific Gnas ${ }^{\triangle C D 4}$ mice, we crossed Gnas ${ }^{\triangle C D 4}$ to OT-2 mice. Seven- to 12 -week-old mice were used in all the experiments and were maintained under specific pathogen-free conditions.

Reagents. Reagents were obtained as follows: 8Br-cAMP and PKA inhibitor H-89 from Calbiochem; recombinant cytokines (IL-23, IL-1 $\beta$, and IL-6) and anti-mouse CD28 Ab from eBioscience; human recombinant TGF- $\beta$ from PeproTech; IL-2 from Sigma-Aldrich; anti-mouse CD3e (clone 2C11), anti-IL-4 (clone 11B11), and anti-IFN- $\gamma$ (clone XMG1.2) neutralizing antibodies from BioXcell; rolipram and diltiazem from Tocris Bioscience. Tg, forskolin, $\mathrm{PGE}_{2}$, and isoproterenol were purchased from Sigma-Aldrich

$\mathrm{CD}^{+} \mathrm{T}$ cell isolation and differentiation in vitro. $\mathrm{CD} 4^{+} \mathrm{T}$ cells were isolated by immunomagnetic selection (EasySep CD4-negative selection kit, StemCell Technologies) from a single-cell suspension of splenocytes or peripheral lymph node cells. Naive $\mathrm{CD} 4^{+} \mathrm{T}$ cells $\left(\mathrm{CD} 62 \mathrm{~L}^{\text {hi }} \mathrm{CD} 44^{\mathrm{lo}} \mathrm{CD} 25^{-}\right)$were isolated from $\mathrm{CD}^{+} \mathrm{T}$ cells by FACS sorting (Aria, BD Biosciences). Cells were incubated in complete IMDM medium (Invitrogen) supplemented with $2 \mathrm{mM}$ L-glutamine, $100 \mathrm{U} / \mathrm{ml}$ penicillin, $100 \mu \mathrm{g} / \mathrm{ml}$ streptomycin, $50 \mu \mathrm{M}$ $\beta$-mercaptoethanol, and $10 \%$ FCS. Culture plates (48-well) were coated with goat anti-hamster $\mathrm{Ab}\left(0.1 \mathrm{mg} / \mathrm{ml}\right.$, USBiological). Naive $\mathrm{CD}^{+}{ }^{+} \mathrm{T}$ cells $\left(1 \times 10^{6} / \mathrm{ml}\right)$ were cultured in medium with soluble anti-CD3 Ab $(0.25 \mu \mathrm{g} / \mathrm{ml})$, anti-CD28 Ab $(1 \mu \mathrm{g} / \mathrm{ml})$, and neutralizing antibodies for IL-4 $(10 \mu \mathrm{g} / \mathrm{ml})$ and IFN- $\gamma(10 \mu \mathrm{g} / \mathrm{ml})$.

Naive CD4+ $\mathrm{T}$ cells were differentiated into Th17 cells according to two protocols: (a) TGF- $\beta$-dependent Th17 cells were obtained by addition of IL-6 $(20 \mathrm{ng} / \mathrm{ml})$ and TGF- $\beta(4 \mathrm{ng} / \mathrm{ml})$ to the Th0 cultures (34); (b) IL-23-mediated Th17 differentiation by addition of IL- $6(20 \mathrm{ng} / \mathrm{ml}), \mathrm{IL}-23(10 \mathrm{ng} / \mathrm{ml})$, and IL-1 $\beta(10 \mathrm{ng} / \mathrm{ml})(13)$. Naive $\mathrm{CD}^{+} \mathrm{T}$ cells were cultured in goat antihamster Ab-coated culture plates in complete IMDM medium with soluble anti-CD3 Ab $(5 \mu \mathrm{g} / \mathrm{ml})$ and anti-CD28 Ab $(1 \mu \mathrm{g} / \mathrm{ml})$, added with IL-12 $(20 \mathrm{ng} / \mathrm{ml})$ and neutralizing anti-IL-4 Ab $(10 \mu \mathrm{g} / \mathrm{ml})$ for Th1 differentiation; or IL-4 $(10 \mathrm{ng} / \mathrm{ml})$ and neutralizing anti-IFN- $\gamma \mathrm{Ab}(10 \mu \mathrm{g} / \mathrm{ml})$ for Th2 
A

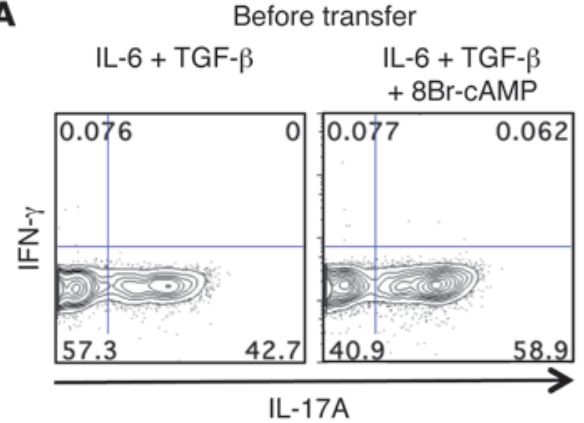

C

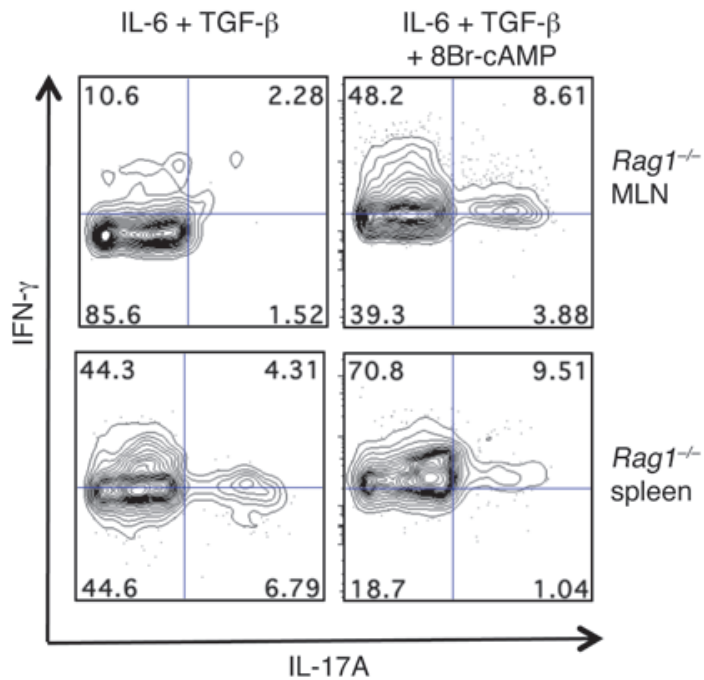

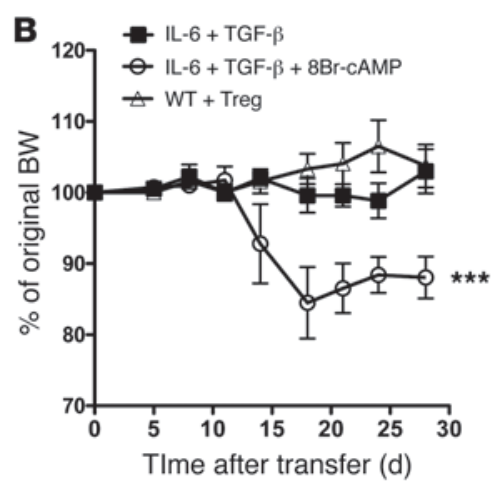

D

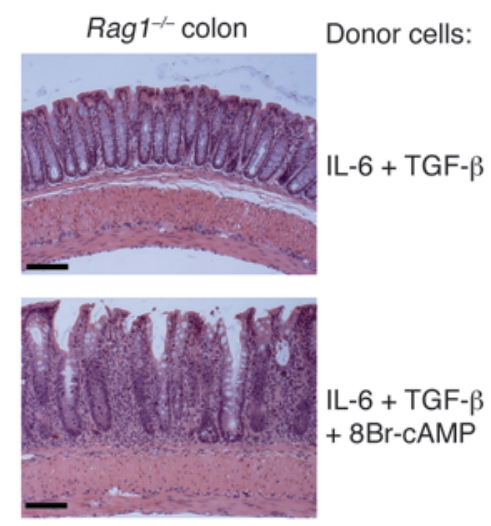

Figure 8

cAMP enhances the colitogenicity of in vitro differentiated Th17 cells. FACS-sorted naive CD4+ T cells from WT spleens were cultured for 4 days under Th17 differentiation conditions (IL-6/TGF- $\beta$ ) with or without 8Br-cAMP $(25 \mu \mathrm{M})$ and then adoptively transferred into Rag $1^{-/-}$mice. (A) Intracellular expression of IFN- $\gamma$ and IL-17A in Th17 cells before transfer. (B) Percentage of initial body weight of Rag $1^{-/-}$recipients after transfer of Th17 cells (differentiated in vitro with or without $8 \mathrm{Br}$-CAMP). The co-transfer of WT CD4+CD45RB ${ }^{\text {hiCD25- }}{ }^{-}$cells with $\mathrm{CD}^{+} 45 \mathrm{RB}^{\mathrm{lo}} \mathrm{CD} 25^{+} \mathrm{Tregs}$ was used as control. Data are shown as mean \pm SEM; $n=3-5 ;{ }^{* \star *} P<0.001$, 2-way ANOVA, recipients receiving in vitro differentiated Th17 cells with or without 8Br-cAMP. (C) Intracellular expression of IFN- $\gamma$ and IL-17A in Th17 cells 28 days after transfer. CD4+ cells from spleen or MLN of recipient mice at day 28 after transfer were stimulated with PMA/ionomycin for 4 hours, and the intracellular cytokine levels were determined by flow cytometry. The number in each quadrant (A and $\mathbf{C})$ indicates the frequency of cells. (D) Histological analysis of the colons of Rag $1^{-1-}$ mice receiving in vitro differentiated Th17 cells with or without 8Br-cAMP (original magnification, $\times 100$, scale bars: $100 \mu \mathrm{M}$ ).

differentiation. At day 2, recombinant human IL-2 $(20 \mathrm{U} / \mathrm{ml})$ was added into the Th1 or Th2 culture. For Treg differentiation, TGF- $\beta(10 \mathrm{ng} / \mathrm{ml})$ and IL-2 $(100 \mathrm{U} / \mathrm{ml})$ were added into IMDM culture medium. After 4 days, cells were collected for analysis.

ELISA measurement of cytokines. Splenic $\mathrm{CD}^{+} \mathrm{T}$ cells were enriched by immunomagnetic cell selection (EasySep CD4 negative selection kit, StemCell Technologies) to greater than $95 \%$ purity by negative selection. CD $4^{+} \mathrm{T}$ cells $\left(1 \times 10^{5}\right.$ cells $)$ were stimulated with plate-bound anti-CD $3 \mathrm{Ab}$ $(10 \mu \mathrm{g} / \mathrm{ml})$ and anti-CD28 Ab $(1 \mu \mathrm{g} / \mathrm{ml})$ for 72 hours in complete RPMI medium (Mediatech Inc.) supplemented with $2 \mathrm{mM}$ L-glutamine, $100 \mathrm{U} / \mathrm{ml}$ penicillin, $100 \mu \mathrm{g} / \mathrm{ml}$ streptomycin, $50 \mu \mathrm{M} \beta$-mercaptoethanol, and $10 \%$ FCS. Cytokine levels in the supernatant were determined using ELISA kits for IL-17A, IL-5, IL-10, TNF- $\alpha$, IFN- $\gamma$ (eBioscience), and IL-22 (Antigenix America Inc.) following the manufacturers' instructions.

Flow cytometry and intracellular staining. All antibodies used for cell labeling were purchased from BD Biosciences - Pharmingen and eBiosciences. The data were acquired by an LSR II, FACSCalibur, and C6
Accuri flow cytometer (BD Biosciences) and analyzed by FlowJo software (Tree Star Inc.). For measurements of intracellular cytokines, CD4 ${ }^{+}$ $\mathrm{T}$ cells were stimulated with PMA $(50 \mathrm{ng} / \mathrm{ml})$ and ionomycin $(1 \mu \mathrm{M})$ in the presence of GolgiStop (BD Biosciences - Pharmingen) for 4 hours. Cytokines were analyzed using antibodies to IL-17A, TNF- $\alpha$, IL-4, Foxp3, or IFN- $\gamma$ (eBioscience) according to the manufacturer's instructions. For measurements of p-Stat 3 levels, we incubated $\mathrm{CD}^{+} \mathrm{T}$ cells with anti-CD3 $(10 \mu \mathrm{g} / \mathrm{ml})$ and anti-CD28 $(1 \mu \mathrm{g} / \mathrm{ml})$ Abs with the indicated cytokines for 15 minutes. Cells were fixed by $1.5 \%$ formaldehyde, $100 \%$ methanol, and stained by anti-p-Stat $3-P E A b$ (pY705, BD Biosciences - Pharmingen).

cAMP assay. cAMP accumulation was measured as previously described (35). $\mathrm{CD}^{+} \mathrm{T}$ cells or $\mathrm{CD} 11 \mathrm{c}^{+}$BMDCs were enriched by magnetic selection and equilibrated in RPMI- 1640 medium containing 10\% FCS for 30 minutes at $37^{\circ} \mathrm{C}$ and then incubated with stimulatory agonists for 10 minutes in the absence and presence of PDE inhibitors (added 30 minutes before the addition of agonists). Reactions were terminated by aspiration of the 
medium and addition of $50 \mu \mathrm{l}$ of cold $7.5 \%$ (wt/vol) trichloroacetic acid (TCA) per million cells. cAMP content in TCA extracts was determined by radioimmunoassay and normalized to the amount of cells per well.

OVA-specific immune responses upon in vitro immunization. Naive OT-2 $\mathrm{CD} 4^{+} \mathrm{T}$ cells from spleens of WT or Gnas ${ }^{\triangle C D 4}$ mice were enriched by immunomagnetic cell selection (EasySep CD4 negative selection kit, StemCell Technologies) to greater than $95 \%$ purity and were further depleted of CD25 $5^{+}$cells (anti-CD25 Biotin Ab and Biotin selection kit, StemCell Technologies) by negative selection. The WT splenic DCs were isolated by use of a $\mathrm{CD} 11 \mathrm{c}$ positive selection kit (StemCell Technologies). DCs $\left(0.5 \times 10^{6}\right)$ were then cocultured with WT or OT-2/Gnas ${ }^{\triangle C D 4}$ naive T cells $\left(1 \times 10^{6}\right)$ in RMPI-1640 medium in the presence of class II OVA peptide (aa 323-339) $(10 \mu \mathrm{g} / \mathrm{ml}$ ) for 5 days. OT-2 cells $\left(1 \times 10^{5}\right)$ were then collected and stimulated by plate-bound anti-CD3 Ab $(10 \mu \mathrm{g} / \mathrm{ml})$ and soluble anti-CD28 Ab $(1 \mu \mathrm{g} / \mathrm{ml})$ for 24 hours. Supernatants were collected and cytokine levels were determined (ELISA).

OralCT/OVA immunization. Mice were immunized orally by gavage on day 0 and day 14 with CT (20 $\mu \mathrm{g}$, List Laboratories) and OVA (200 $\mu \mathrm{g}$, SigmaAldrich), as described previously (7). On day 39 , the mice were challenged with OVA (200 $\mu$ g i.p.). Single-cell suspensions from spleens were collected on day 42 and incubated for 3 days with medium alone or supplemented with OVA $(200 \mu \mathrm{g} / \mathrm{ml})$. The concentration of cytokines in the supernatants was determined by ELISA.

$\mathrm{Ca}^{2+}$ flux measurement. Splenic CD4+ $\mathrm{T}$ cells were loaded for 10 minutes at $37^{\circ} \mathrm{C}$ with CFSE $(20 \mathrm{nM})$, followed by washing. Equal numbers of CFSE-labeled WT CD4 ${ }^{+} \mathrm{T}$ cells were mixed with the unlabeled Gnas ${ }^{\Delta C D 4}$ $\mathrm{CD} 4^{+} \mathrm{T}$ cells. Cells were suspended at a density of $1 \times 10^{7}$ cells per $\mathrm{ml}$ in $\mathrm{Ca}^{2+}$-free and $\mathrm{Mg}^{2+}$-free HBSS supplemented with $2 \% \mathrm{FCS}$ and incubated for 1 hour at $37^{\circ} \mathrm{C}$ in $5 \% \mathrm{CO}_{2}$ with the calcium indicator Indo-1 AM (36) ( $2 \mu \mathrm{M}$; Molecular Probes, Invitrogen). Cells were washed with HBSS medi$\mathrm{um}$ and were treated for 30 minutes on ice with anti-CD3 (clone 2C11) Ab and APC-conjugated anti-CD4 Ab (GK1.5, eBioscience). Cells were washed once with HBSS, placed on ice for 1 hour, and rewarmed to $37^{\circ} \mathrm{C}$ before data analysis on an LSR II (BD). For cell stimulation, goat anti-hamster Ab $(5 \mu \mathrm{g} / \mathrm{ml})$ was added to crosslink CD3 Abs. $\mathrm{CaCl}_{2}(2 \mathrm{mM})$ and 8Br-cAMP $(50 \mu \mathrm{M})$ were added as indicated. In some experiments, $\mathrm{CD} 4^{+} \mathrm{T}$ cells were preincubated with the PKA inhibitor $\mathrm{H}-89(10 \mu \mathrm{M})$ for 15 minutes at $37^{\circ} \mathrm{C}$. The data are presented as the ratio of violet $(405 \mathrm{~nm})$ to blue $(510 \mathrm{~nm})$ Indo-1 fluorescence and were calculated using FlowJo (Tree Star Inc.).

Adoptively transferred $\mathrm{CD}^{+} \mathrm{T}$ cells induced colitis. Colitis was induced by adoptive transfer of naive $\mathrm{CD} 45 \mathrm{RB}^{\mathrm{hi}} \mathrm{CD} 4^{+} \mathrm{T}$ cells: sorted naive $\mathrm{CD} 4^{+} \mathrm{T}$ cells $\left(\mathrm{CD} 4^{+} \mathrm{CD}^{2} \mathrm{RB}^{\mathrm{hi}} \mathrm{CD} 25^{-}, 1 \times 10^{5}\right.$ cells/mouse) from WT or Gnas ${ }^{\Delta \mathrm{CD} 4}$ spleen were adoptively transferred into 12 -week-old sex- and age-matched Rag $1^{-/}$ mice as described previously (37). A group of Rag $1^{-/-}$mice also received
$0.5 \times 10^{5} \mathrm{CD}^{2} 5 \mathrm{RB}^{\text {lo }} \mathrm{CD}^{2} 5^{+}$(Tregs) from WT mice; naive CD4+ $\mathrm{T}$ cells $\left(1 \times 10^{5}\right.$ cells) were used controls. After transfer, mice were monitored for weight loss and signs of intestinal inflammation. Diseased animals were sacrificed for analysis between 4 and 6 weeks after transfer. Splenic and mesenteric lymph node (MLN) cells were cultured in RPMI-1640 medium and stimulated by PMA/ionomycin for 5 hours in the presence of GolgiStop (BD Biosciences - Pharmingen) for intracellular staining. The colon explants were isolated and cultured as described previously (37), and cytokines levels in the supernatant were measured (ELISA).

Histological evaluation of colitis. The colon was excised, opened longitudinally, rolled onto a wooden stick, fixed with $10 \%$ neutral buffered formaldehyde solution, and embedded in paraffin. Tissue sections $(5 \mu \mathrm{m})$ were prepared, deparaffinized, and stained with H\&E. Sections were analyzed in a blinded fashion as described in previous studies (37).

Quantitative PCR analysis. Isolation of RNA was carried out using an RNeasy Mini Kit (QIAGEN) according to the manufacturer's instructions. The cDNA was synthesized using Superscript III First-Strand system (Invitrogen). Quantitative PCR analysis was performed as described previously (37). SYBR Green PCR Master Mix was used for real-time PCR (7300 system, Applied Biosystems). Samples were run in duplicate or triplicate and normalized by a housekeeping gene (mouse Rplp0 and mouse $18 \mathrm{~s}$ rRNA). The primer sequences are provided in Supplemental Table 1.

Statistics. Data are presented as mean \pm SEM. Unpaired Student's $t$ test with 2-tailed $P$ values was used for statistical analyses unless indicated otherwise (GraphPad Prism software). In all tests, $P$ values less than 0.05 were considered statistically significant.

Study approval. All experimental procedures were approved by the UCSD IACUC.

\section{Acknowledgments}

We thank Liang Zhou, Dianel Mucida, Jongdae Lee, and Nakon Aroonsakool for technical help and discussion. This study was supported by NIH grants AI068685, AI095623, AI077989, DK35108, DK080506, and T32 AI7469 and a grant from the Crohn's and Colitis Foundation of America.

Received for publication May 19, 2011, and accepted in revised form January 4, 2012.

Address correspondence to: Eyal Raz, Department of Medicine 0663, University of California San Diego, La Jolla, California 92093-0663, USA. Phone: 858.534.5444; Fax: 858.534.0409; E-mail:eraz@ucsd.edu.
1. Weinstein LS, Liu J, Sakamoto A, Xie T, Chen M. Minireview: GNAS: normal and abnormal functions. Endocrinology. 2004;145(12):5459-5464.

2. Bender AT, Beavo JA. Cyclic nucleotide phosphodiesterases: molecular regulation to clinical use. Pharmacol Rev. 2006;58(3):488-520.

3. Mosenden R, Taskén K. Cyclic AMP-mediated immune regulation - overview of mechanisms of action in T cells. Cell Signal. 2011;23(6):1009-1016.

4. Yao C, et al. Prostaglandin E2-EP4 signaling promotes immune inflammation through Th1 cell differentiation and Th17 cell expansion. Nat Med. 2009; 15(6):633-640.

5. Napolitani G, Acosta-Rodriguez EV, Lanzavecchia A, Sallusto F. Prostaglandin E2 enhances Th17 responses via modulation of IL-17 and IFN-gamma production by memory $\mathrm{CD} 4^{+} \mathrm{T}$ cells. Eur I Immunol. 2009;39(5):1301-1312.

6. Boniface K, et al. Prostaglandin E2 regulates Th17 cell differentiation and function through cyclic AMP and EP2/EP4 receptor signaling. J Exp Med.
2009;206(3):535-548

7. Datta SK, et al. Mucosal adjuvant activity of cholera toxin requires Th17 cells and protects against inhalation anthrax. Proc Natl Acad Sci U S A. 2010; 107(23):10638-10643.

8. Chen $\mathrm{M}$, et al. Increased glucose tolerance and reduced adiposity in the absence of fasting hypoglycemia in mice with liver-specific Gs alpha deficiency. J Clin Invest. 2005;115(11):3217-3227.

9. Darfler FJ, Mahan LC, Koachman AM, Insel PA. Stimulation of forskolin of intact S49 lymphoma cells involves the nucleotide regulatory protein of adenylate cyclase. J Biol Chem. 1982; 257(20):11901-11907.

10. Brand S. Crohn's disease: Th1, Th17 or both? The change of a paradigm: new immunological and genetic insights implicate Th17 cells in the pathogenesis of Crohn's disease. Gut. 2009;58(8):1152-1167.

11. Liu ZJ, Yadav PK, Su JL, Wang JS, Fei K. Potential role of Th17 cells in the pathogenesis of inflammatory bowel disease. World J Gastroenterol.
2009;15(46):5784-5788

12. Ma J, McCarl CA, Khalil S, Lüthy K, Feske S. T-cellspecific deletion of STIM1 and STIM2 protects mice from EAE by impairing the effector functions of Th1 and Th17 cells. Eur J Immunol. 2010; 40(11):3028-3042.

13. Ghoreschi $\mathrm{K}$, et al. Generation of pathogenic $\mathrm{T}(\mathrm{H}) 17$ cells in the absence of TGF-beta signalling. Nature. 2010;467(7318):967-971.

14. Zhou L, Littman DR. Transcriptional regulatory networks in Th17 cell differentiation. Curr Opin Immunol. 2009;21(2):146-152.

15. Ivanov II, et al. The orphan nuclear receptor RORgammat directs the differentiation program of proinflammatory IL-17 $7^{+} \mathrm{T}$ helper cells. Cell. 2006; 126(6):1121-1133.

16. Durant L, et al. Diverse targets of the transcription factor STAT3 contribute to T cell pathogenicity and homeostasis. Immunity. 2010;32(5):605-615.

17. Yang XO, et al. STAT3 regulates cytokine-mediated generation of inflammatory helper $\mathrm{T}$ cells. 
J Biol Chem. 2007;282(13):9358-9363.

18. McCarl CA, et al. Store-operated $\mathrm{Ca}^{+}$entry through ORAI1 is critical for T cell-mediated autoimmunity and allograft rejection. J Immunol. 2010; 185(10):5845-5858.

19. Matza D, Flavell RA. Roles of $\mathrm{Ca}(\mathrm{v})$ channels and AHNAK1 in T cells: the beauty and the beast. Immunol Rev. 2009;231(1):257-264.

20. Kesten KS, Reuter NS, Swisher JD. Diltiazem: the latest calcium-channel blocker. Dimens Crit Care Nurs. 1984;3(3):154-160.

21. Conche C, Boulla G, Trautmann A, Randriamampita $C$. T cell adhesion primes antigen receptorinduced calcium responses through a transient rise in adenosine $3^{\prime}, 5^{\prime}$-cyclic monophosphate. Immunity. 2009;30(1):33-43.

22. Zhou L, Chong MM, Littman DR. Plasticity of $\mathrm{CD} 4{ }^{+} \mathrm{T}$ cell lineage differentiation. Immunity. 2009; 30(5):646-655.

23. Adams GB, et al. Haematopoietic stem cells depend on Galpha(s)-mediated signalling to engraft bone marrow. Nature. 2009;459(7243):103-107.

24. Weinstein LS. Gs alpha knockouts in mice and man. Rinsho Byori. 1999;47(5):425-429.

25. Matza D, et al. A scaffold protein, AHNAK1, is required for calcium signaling during T cell activation.
Immunity. 2008;28(1):64-74.

26. Oh-hora M. Calcium signaling in the development and function of T-lineage cells. Immunol Rev. 2009;231(1):210-224.

27. Hell JW. Beta-adrenergic regulation of the L-type $\mathrm{Ca}^{+}$channel $\mathrm{Ca}(\mathrm{V}) 1.2$ by PKA rekindles excitement. Sci Signal. 2010;3(141):pe33.

28. Yatani A, Imoto Y, Codina J, Hamilton SL, Brown AM, Birnbaumer L. The stimulatory G protein of adenylyl cyclase, Gs, also stimulates dihydropyridine-sensitive $\mathrm{Ca}_{2}{ }^{+}$channels. Evidence for direct regulation independent of phosphorylation by cAMP-dependent protein kinase or stimulation by a dihydropyridine agonist. J Biol Chem. 1988; 263(20):9887-9895.

29. Mattera R, et al. Splice variants of the alpha subunit of the $G$ protein $G$ s activate both adenylyl cyclase and calcium channels. Science. 1989;243(4892):804-807.

30. Nair BG, Parikh B, Milligan G, Patel TB. Gs alpha mediates epidermal growth factor-elicited stimulation of rat cardiac adenylate cyclase.J Biol Chem. 1990; 265(34):21317-21322.

31. Poppleton H, Sun H, Fulgham D, Bertics P, Patel TB. Activation of Gsalpha by the epidermal growth factor receptor involves phosphorylation. J Biol Chem. 1996;271(12):6947-6951.
32. Sun $\mathrm{H}$, et al. The juxtamembrane, cytosolic region of the epidermal growth factor receptor is involved in association with alpha-subunit of Gs. J Biol Chem. 1997;272(9):5413-5420.

33. Weber KS, Miller MJ, Allen PM. Th17 cells exhibit a distinct calcium profile from Th1 and Th2 cells and have Th1-like motility and NF-AT nuclear localization. J Immunol. 2008;180(3):1442-1450.

34. Zhou L, et al. IL-6 programs T(H)-17 cell differentiation by promoting sequential engagement of the IL-21 and IL-23 pathways. Nat Immunol. 2007; 8(9):967-974.

35. Murray F, et al. Expression and activity of cAMP phosphodiesterase isoforms in pulmonary artery smooth muscle cells from patients with pulmonary hypertension: role for PDE1. Am J Physiol Lung Cell Mol Physiol. 2007;292(1):L294-L303.

36. Fu G, Gascoigne NR. Multiplexed labeling of samples with cell tracking dyes facilitates rapid and accurate internally controlled calcium flux measurement by flow cytometry. J Immunol Methods. 2009; 350(1-2):194-199.

37. Gonzalez-Navajas JM, et al. TLR4 signaling in effector $\mathrm{CD}^{+} \mathrm{T}$ cells regulates TCR activation and experimental colitis in mice. J Clin Invest. 2010; 120(2):570-581. 